\title{
Lilac Cultivar Name Registration 2002
}

\author{
Freek Vrugtman ${ }^{1}$ \\ Royal Botanical Gardens, Box 399, Hamilton, Ontario L8N 3H8, Canada
}

\begin{abstract}
All correspondence concerned with additional information or plants or propagules of newly registered lilac cultivars should be directed to the registrants listed below, not to the Registrar.

Commencing with 1995 Lilac Registrations Standard portfolios are being established in accordance with Principle 3 and Articles 12, 22 (Recommendations $22 \mathrm{G} \& 22 \mathrm{H}$ ), and 32 of the International Code of Nomenclature for Cultivated Plants-1995 (ICNCP-1995).

Previous registration lists of Syringa cultivar names appeared in AABGA Bulletin [13(4):105-110; 14(3):95; 15(3):71-72; 16(4):131132; 17(3):67-69; 18(3):87]; HortScience [23(3):458; 24(3):435-436; 25(6):618;26(5):476-477;29(9):972;31(3):327-328;32(4):587-588; 33(4):588-589; 34(4):600; 35(4):549; 36(5):836; 37(7):1145].
\end{abstract}

Syringa pubescens subsp. patula (Palib.) M.C. Chang \& X.L. Chen 'Klmone' was registered 4 June 2002 by Roy G. Klehm, 197 West Penny Road, South Barrington, IL 60010, USA. Selected by Mr. Klehm the lilac was introduced as Miss SUSIE ${ }^{\mathrm{TM}}$ in 2001 by Beaver Creek Nursery, Inc., Grove, Ill., (Plant Line ${ }^{\mathrm{TM}}$ Summer 2001, p. 18). Cultivar name and color illustration appear on p. 87, 2002 Retail Catalog, Klehm's Song Sparrow Perennial Farm, Avalon, Wisconsin. Mr. Klehm's selection has been traced back to an unnamed seedling of unknown parentage in the lilac collection of the city of Brighton, United Kingdom; material was received by Royal Botanical Gardens, Hamilton, Ontario, Canada (accession m72015), and passed on to Longenecker Horticultural Gardens (accession m84012). Mr. Klehm first observed the flowers and made his selection in 1992, initial propagation in 1993, naming of the cultivar about 1996, trademark ascribed in 2000. 'KLMONE' blooms at the same time as 'Miss Kim', but the color of the florets is much lighter and softer; leaf characteristics and habit are similar to 'Miss Kim'. Florets single, $1 \mathrm{~cm}$ in diameter, fragrant. Flower buds Red Group 54b (RHS Colour Chart, 1966), opening to White Group 155d. The fall color of the foliage is gold to golden brown. Winter hardiness: $5 \mathrm{a}$, possibly $4 \mathrm{~b}$. The preferred method of propagation is softwood cuttings. A Standard portfolio has been opened at Royal Botanical Gardens Herbarium, Hamilton, Ontario, Canada, but is still incomplete.

Syringa reticulata subsp. pekinensis P.S. Green \& M.C. Chang 'Morton' was registered 2 Aug. 2002 by Angela T. Palmer, Plant Introduction Manager, Chicagoland Grows ${ }^{\circledR}$, Inc., 1000 Lake Cook Road, Glencoe, IL 60022 USA. The original plant was grown from seed collected by Joseph F.C. Rock (1884-1962) in Oct. 1926 near Lienhoa Shan, Gansu (Kansu) province, China, at an elevation of $2700 \mathrm{~m}$, for the Arnold Arboretum; collection m 13506. The plant was selected from a batch of seedlings received by The Morton Arboretum from the Arnold Arboretum. At the Morton Arboretum the seed-lot was accessioned as MA m 172-26sd; the selected seedling is accessioned as MA m 2391-sd. In 1988 the selection was named 'Morton' by Kris Bachtell, Director of Collections and Grounds, The Morton Arboretum, Lisle, Il. Initial vegetative propagation took place in 1988; the preferred method of propagation is through tissue culture. Plants have flowered in the third year after propagation. Initial distribution of this clone took place in 1991. The cultivar name 'Morton' was first published in 1992. At the age of 75 years 'Morton' is a 12-m-tall tree with a nearly globose crown, the width being $80 \%$ to $90 \%$ of its height. Thyrses 17 to $25 \mathrm{~cm}$ long and 15 to $18 \mathrm{~cm}$ in diameter. Florets single, $8 \mathrm{~mm}$ in diameter. Flower buds Orange-White Group 159D (RHS Colour Chart, 1986), opening to creamy-white. Flower fragrance often strong, resembling the fragrance of privet. Foliage green, with autumn coloration. Known to be hardy in USDA Zones 5 to 8. This selection has proven to be highly tolerant of de-icing salts. Trademarks registered for 'Morton' are WATER TOWER ${ }^{\circledR}(\mathrm{m} 1,697,063)$ and CHINA $\mathrm{SNOW}^{\circledR}(\mathrm{m} 2,009,915)$. At one time or other 'Morton' has been referred to erroneously as 'Chicago Tower' and 'Watertown'. A Standard portfolio has been opened at Royal Botanical Gardens Herbarium, Hamilton, Ontario, Canada. Selected literature references are:

McKelvey, S. D. 1928. The Lilac-A Monograph. p. 496-497. Macmillan, New York.

Bachtell, K.R. 1991. Peking lilac (Syringa pekinensis). The Morton Arboretum Quarterly 27(1):10-12.

Bachtell, K.R. 1994. Chicagoland Grows: A marketing system for new plants. Combined Proceedings International Plant Propagators' Society 44:571.

Syringa reticulata subsp. reticulata 'Golden Eclipse' was registered 2 Aug. 2002, by John Bakker III of J.C. Bakker \& Sons Ltd., 1360 Third Street, St Catharines, Ontario L2R 6P9, Canada. The original seedling of open-pollinated parentage was found in 1995 at the J.C. Bakker \& Sons Ltd. nursery, selected by Rob Bakker, and named by John Bakker III. The name was chosen because of the leaf's golden variegation, which eclipses as the season progresses. Initial vegetative propagation took place in 1996; the preferred method of propagation is through summer budding to Syring a reticulata understock. Plants have flowered in the third year after propagation. This selection resembles 'Ivory Silk' in growth rate and habit, except for its golden variegated foliage. In early spring the leaves unfold with bright golden variegated and undulated margins, and a dark green center. As the season progresses the golden margins fade to a lighter green; the foliage shows excellent resistance to sunburn. All trials have shown that the leaf variegation is persistent; no reverting has been observed. The flowering habit is identical to that of 'Ivory Silk'. The name 'Golden Eclipse' was first published, with a description of the cultivar, on p. 12 of the J.C. Bakker \& Sons Ltd. 2000-2001 Reference Guide. An application for plant breeders' rights has been filed with the Plant Breeders' Rights Office, Canada (application \# 01-2536 dated 2001-02-26). A Standard portfolio has been opened at Royal Botanical Gardens Herbarium, Hamilton, Ontario, Canada, but is still incomplete. 